\title{
Democracy, Civil Society and Sexual Citizenship
}

\author{
Sharyn Graham Davies \\ Sharyn.davies@aut.ac.nz
}

\begin{abstract}
This talk will address the ways in which democracy has impacted civil society and sexual citizenship. When Indonesia became a democracy in 1998, after many decades of authoritarian rule, many in the country and beyond hoped that civil society and sexual citizenship would be given the opportunity to flourish. For the first decade, flourishing was indeed evident in many sectors. New media freedoms encouraged a proliferation of films, many of them dealing explicitly with sexual citizenship. The influence of international human rights organisations saw sexual health care being addressed at a national level. Regional autonomy enabled local provinces to establish their own policies and in some cases, such as East Timor, being granted independence. But with democracy also came a restriction of rights for many. Indeed, as this paper shows, at the time of its writing, August 2017, democracy has not guaranteed the rights of all Indonesian citizens and in fact in many ways sexual citizenship is now more restricted than it was under authoritarian rule. This talk builds on a chapter I am writing with Hendri Yulius for a book edited by Michele Ford. It also builds on a chapter I am writing for a book edited by Robert Hefner. I would like to thank the organisers of this conference and Dzuriyatun Toyibah for inviting me to attend.
\end{abstract}

Keyword : Democracy, Civil Society, Sexual Citizenship

\section{INTRODUCTION}

The mention of the transition to democracy brings hope for many that the country in question will soon operate on the basis of ensuring that all citizens have access to equal representation and participation [1]. It is expected, then, that citizens who are claiming rights on the basis of gender or sexual orientation will be shortly accorded basic human rights. These human rights should include negative rights such as the right not to be discriminated on the basis of gender or sexuality, and it should include positive rights such as the right to be able to form loving relationships [2]. In many cases the move towards democracy does indeed mean that individuals receive both positive and negative rights. For instance, during the transition to democracy marriage equality was legalised in countries such as Argentina, Brazil and South Africa [3][4][5]. But of course such a transition does not always accord with human rights. For instance, India has regressed on according basis human rights to people on the basis of sexuality [6].

What then has happened in Indonesia in the democratic era in terms of allocating human rights on the basis of sexual citizenship? In order to address that question this talk is made up of three key parts. First I will talk about sexual citizenship prior to democracy. Second I will talk about sexual citizenship in the first few years of democracy. Third I will talk about how democracy has impacted sexual citizenship in the present day, two decades after Indonesia moved away from authoritarian rule to democracy. What I argue in this talk is that while democracy should have been a good thing for civil society and sexual citizenship, the negative forces that can appear in a democracy, such as homophobia, have been left unchecked and as a consequence the current environment permits the harassment and persecution of individuals and groups on the basis of sexual identity. While it was somewhat encouraging that Jokowi has publicly stated that people should not be harassed on the basis of sexual identity, he and his government need to do much more to protect the right of all Indonesians.

\section{CIVIL SOCIETY AND SEXUAL CITIZENSHIP BEFORE DEMOCRACY}

During authoritarian rule there was little scope for the development of civil society or sexual citizenship in Indonesia. President Suharto, and President Sukarno prior to that, kept tight reigns on society and officially permitted only those organisations that would foster the idea of Indonesia that the presidents envisaged. There was, however, the development of many civil society organisations that kept themselves under the government's radar. There were in fact a few lesbian organisations that developed to link women across the archipelago and encourage these women to have a sense of self-acceptance. A number of gay organisations also developed, although many of them were short lived. Increasingly these organisations drew on international literature concerning gender and sexual identity and while not adopting the language or the sentiment of much of this literature, many organisations found it useful in the development of a sense of community [7].

A key influence in the development of civil society organisations was the need to raise awareness of the importance of sexual health, particularly once HIV became an issue in Indonesia. Many organisations were thus able to tap into health care as a way to simultaneously connect lesbians and gay men. By concealing much of their activist work, many civil society organisations committed to ensuring sexual citizenship for all Indonesians were able to grow an activist movement that, when the time come, could take advantage of democratic reforms.

\section{WHEN DEMOCRACY CAME}

When democratic reforms took hold in Indonesia starting in 1998, there was great hope among many that civil society and sexual citizenship would be advantaged by a new discourse of human rights. Events such as film festivals, which showcased some amazing cinema being produced in Indonesia, showed to an international audience that citizens 
could express a sense of self free from overt government regulation [8]. Civil society organisations committed to sexual diversity, such as Suara Kita, Ardhanary Institute and GAYa Nusantara, were able to receive funding and technical assistance from international donors to increase their advocacy of human rights.

In 2006 the Yogyakarta Principles on the Application of International Human Rights Law in relation to Sexual Orientation and Gender Identity were signed in Indonesia. That Indonesia committed itself to upholding the basic human rights of all citizens regardless of gender or sexual orientation placed Indonesia among the leaders in Asia on the issue of sexual freedom. Further, the National Commission on Violence against Women (Komnas Perempuan) and the National Commission on Human Rights (Komnas HAM) also joined with lesbian and gay organisations to promote the human rights of all Indonesian citizens. Sadly, however, it was not just progressive organisations that used democracy to make its claims known. As the next section shows, the conservative elements of Indonesian society were also able to use democratic principles to undermine the human rights of Indonesian citizens.

\section{DEMOCRACY SPURNS DISCONTENT}

Just as progressive forces can use democracy, so too can conservative ones. Indeed Indonesia has become an exemplary case of where conservative elements of society have been able to use democracy to meet non-progressive ends. In particular, it was been religious conservatives who have utilized the freedoms available through democratic reform. Interestingly, under Suharto religious expression was controlled in a top down manner. Suharto was in many ways worried that Islamic elements might grow strong enough to challenge his power. To this end, Suharto kept a tight lid on Islamic organisations [9][10]. But as the New Order waned, restrictions on Islamic expression were lifted [11]. Islamic groups grew in power and thus were well placed to make vocal demands in the democratic era [12].

One of the most vocal religious groups to emerge in the democratic era was the Islamic Defenders Front (FPI). Of particular concern to FPI members was the expression of sexual citizenship. FPI began to pay increasingly violent attention to the activities of anyone they saw not conforming to their image of hetero normative sexuality. FPI members thus began raiding various events such as the international lesbian and gay conference held in 2010 [13]. Such was the power of FPI that many otherwise progressive Indonesians began to either support homophobia rhetoric, or do nothing to force its cessation.

By the early 2000s the Ministry of Justice and Human Rights began considering a change to the Criminal Code to penalise for the first time in Indonesia's history homosexuality [14]. In 2008, Indonesia passed the draconian Anti-Pornography law which frames transgender and homosexuality as impermissible. Regional autonomy enabled provinces such as Aceh to implement Islamic Criminal Code Bylaws penalising with imprisonment and canning homosexual acts. By 2016, homophobia had reach an all-time high [15][16]. High-ranking politicians came out in the media exhorting for a law change that would make homosexuality and transgenderism illegal.

While civil society and sexual citizenship are more at risk now than at any other in point in democratic Indonesia's history, activists have not simply resigned their fate to a homophobic state. Rather activists and others have strategically sought ways to bring a human rights agenda to the fore. Film festivals are still held but not publically advertised; lectures are still given at universities but again they are not publicly advertised; while Indonesia has refused to accept United Nations funding for projects ear-marked for lesbian and gay groups, activities still happen under the banner of health care. While democracy, it seems at this point, has not been wholly advantageous for civil society and sexual citizenship, there is still hope.

\section{CONCLUSION}

While in many ways this is a depressing talk, I want to end with a note of hope. Indonesia is an incredibly diverse country with a long history of not only tolerating but supporting and celebrating gender and sexual diversity (Davies 2015). With such a history, and such a body of largely tolerant and accepting citizenships, I hope that the future is brighter than it is now for both civil society and sexual citizenship. Thank you all for your attention. 


\section{References}

[1] Macgillivray, I. (2000). Educational Equity for Gay, Lesbian, Bisexual, Transgendered, and Queer/Questioning Students: The Demands of Democracy and Social Justice for America's Schools. Education and Urban Society, 32(3), 3449.

[2] Drucker, P. (2015). Gay Normality and Queer Transformation. Zapruder World: An International Journal for the History of Social Conflict, available at: http://www.zapruderworld.org/content/peter-drucker-gaynormality-and-queer-transformation.

[3] Brown, S. (1999). "Democracy and Sexual Difference: The Lesbian and Gay Movement in Argentina," in Adam, Barry D., Jan W. Duyvendak, \& Andre Krouwel (Eds.), The Global Emergence of Gay and Lesbian Politics. Philadelphia: Temple University Press.

[4] Green, J. N. (1999). Beyond Carnival: Male Homosexuality in Twentieth-Century Brazil. Chicago: University of Chicago Press.

[5] Palmberg, M. (1999). Emerging Visibility of Gays and Lesbians in Southern Africa: Contrasting Contexts," in Adam, B. , J. Duyvendak , \& A. Krouwel, (Eds.), The Global Emergence of Gay and Lesbian Politics. Philadelphia: Temple Univ. Press.

[6] Encarnación, O. (2014). Gay Rights: Why Democracy Matters. Journal of Democracy, 25(3), 90-104.

[7] Boellstorff, T. (2005). The Gay Archipelago: Sexuality and Nation in Indonesia. Princeton: Princeton University Press.

[8] Maimunah. (2008). Indonesia's Q! Film Festial: Young Indonesians are Using an Alternative Film Festival to Promote Sexual Diversity. Inside Indonesia 93 (JulySeptember). Available at: www.insideindonesia.org.

[9] Aspinall, E. (2009). Islam and Nation: Separatist Rebellion in Aceh, Indonesia. Stanford: Stanford University Press.

[10] Hefner, R. (2000). Civil Islam: Muslims and Democratization in Indonesia. Princeton: Princeton University Press.Human Rights Watch. (2016). 'These Political Games Ruin our Lives': Indonesia's LGBT Community under Threat. Available at: http://www.hrw.org/1-91.

[11] Wichelen, S. (2010). Religion, Politics and Gender in Indonesia: Disputing the Muslim Body. London: Routledge.

[12] Robinson, K. (2011). Sawerigading vs. Sharia: Identities and Political Contestation in Decentralised Indonesia. Asian Journal of Social Science, 39(2), 219-237.

[13] Marching, S. T. (2010). ILGA dan Anak Itik (ILGA and Duck). Bhinneka Magazine, 6.

[14] Offord, B. (2011). Singapore, Indonesia and Malaysia: Arrested Development! In M. Tremblay, D. Patternotte, \& C. Johnson (Eds.), The Lesbian and Gay Movement and the State (pp. 135-152). UK: Ashgate

[15] Boellstorff, T. (2016). Against State Straightism: Five Principles for Including LGBT Indonesians. E-International Relations, available at: http://www.eir.info/2016/03/21/against-state-straightism-five-principlesfor-including-lgbt-indonesians/
[16] Davies, S. G. (2016). Indonesia’s Anti-LGBT Panic. East Asia Forum, 8(2), 8-11.

[17] Davies, S. G. (2015). Sexual Surveillance. In L. R. Bennett \& S. G. Davies (Eds.), Sex and Sexualities in Contemporary Indonesia: Sexual Politics, Health, Diversity and Representations (pp. 10-31). London: Routledge. 